RAFAL MIE,TKIEWICZ

Akademia Marynarki Wojennej

\title{
Podniesienie poziomu bezpieczeństwa terminala LNG w Świnoujściu poprzez jednoczesne wykorzystanie różnych systemów bezzałogowych
}

\author{
Raising the security of the LNG terminal in Świnoujście \\ with the simultaneous use of various unmanned systems
}

The article presents the author's opinions about raising the security of the LNG Terminal in Świnoujście with the use of various unmanned systems (air, maritime - surface and subsurface). As the terminal is responsible for delivering, storage and further distribution of state energetic safety strategic resources, it requires advanced technology to provide stable exploitation under all conditions.

Keywords: unmanned systems, supplies, modern technologies, LNG Terminal

Słowa kluczowe: systemy bezzałogowe, dostawy, nowoczesne technologie, terminal LNG

\section{Wstęp}

Terminal LNG w Świnoujściu pełni kluczową rolę w dywersyfikacji dostaw surowca o znaczeniu strategicznym dla bezpieczeństwa energetycznego państwa. Umożliwia odbiór gazu pochodzącego od różnych dostawców i z różnych kierunków. Zapewnienie bezpiecznego funkcjonowania tego obiektu ma szczególnie duże znaczenie w wymiarze narodowym, a nawet międzynarodowym, jeśli wziąć pod uwagę plany dystrybucji surowca na południe Europy oraz możliwości tankowania zbiornikowców LNG w żegludze bałtyckiej. Pod wieloma względami terminal jest obiektem bardzo specyficznym, na co wpływa położenie na styku środowisk morskiego i lądowego oraz charakter sprowadzanego i magazynowanego surowca. Utrzymanie wymaganego poziomu bezpieczeństwa tego ważnego obiektu jest zatem kwestią kluczową. Za sprawne i efektywne funkcjonowanie systemu ochrony infrastruktury 
krytycznej odpowiadają dziś systemy wykorzystujące najnowocześniejsze technologie, coraz częściej bezzałogowe (autonomiczne). Do najistotniejszych płynących z tego korzyści zalicza się możliwość prowadzenia nieprzerwanego monitoringu - zarówno w przestrzeni powietrznej, nawodnej, jak i podwodnej - oraz zdolność do przeciwstawienia się wykrytym zagrożeniom natychmiast po wykryciu ich symptomów. Rozwiązanie takie wpływa na skrócenie czasu pomiędzy wykryciem i klasyfikacją niebezpieczeństw a ich zwalczaniem. Należy jednocześnie założyć, że systemy bezzałogowe działające w tak odmiennym środowisku - powietrznym i morskim (nawodnym oraz podwodnym) - charakteryzują się określonymi cechami dodatnimi i ujemnymi. W związku z powyższym sformułowana hipoteza robocza zakłada, że wspólne wykorzystanie powietrznych, nawodnych i podwodnych systemów bezzałogowych może wpłynąć na podniesienie poziomu bezpieczeństwa terminala $\mathbf{L N G}^{1}$. Na potrzeby prowadzonych badań zawężono zakres podejmowanej problematyki, przyjmując do analizy wyłącznie zagrożenia z kierunku morskiego. Dzięki połączeniu architektur odmiennych pod wieloma względami systemów istnieje szansa pokrywania nisz wynikających z ograniczeń poszczególnych systemów dodatnimi parametrami innych. Podstawowymi metodami badawczymi wykorzystanymi do weryfikacji założeń były analiza krytyczna (głównie literatury przedmiotu) oraz wnioskowanie. Artykuł jest rozwinięciem poprzednich badań autora dotyczących wykorzystania technologii bezzałogowych/autonomicznych w obszarze bezpieczeństwa morskiego².

1 Jako wspólne wykorzystanie systemów bezzałogowych operujących w odmiennym środowisku (powietrze, powierzchnia morza oraz toń morska) należy rozumieć użycie systemów autonomicznych realizujących zadania wspólnie, we współdziałaniu w obrębie tego samego systemu bezpieczeństwa. Realizujące działania platformy bezzałogowe przekazują dane $\mathrm{z}$ sensorów na stanowisko dowodzenia, przy czym operatorzy (w zależności od poziomu autonomiczności), wykorzystując ich unikatowe możliwości, są w stanie monitorować szerokie spektrum potencjalnych zagrożeń, a nawet bezpośrednio się im przeciwstawiać. Zwalczanie zagrożeń związane jest jednak z wyposażeniem systemów autonomicznych w środki kinetyczne (w przeważającej większości przypadków) oraz wypracowaniem odpowiednich regulacji prawnych.

2 R. Miętkiewicz, Unmanned surface vehicles in maritime critical infrastructure protection applications - LNG terminal in Świnoujście, ,Scientific Journal of Polish Naval Academy" 2018, R. 59, nr 2 (213), s. 43-51; tenże, Wykorzystanie bezzałogowych jednostek nawodnych w zabezpieczaniu morskich obiektów infrastruktury krytycznej, Akademia Marynarki Wojennej, Gdynia 2018; tenże, Wykorzystanie bezzałogowych systemów morskich w tworzeniu obrazu sytuacji morskiej, [w:] Nauki społeczne i ekonomiczne węzłowe zagadnienia, red. J. Żylińskia, I. Przychocka, Uczelnia Techniczno-Handlowa im. Heleny Chodkowskiej, Warszawa 2017. 


\section{Terminal LNG}

Uruchomienie terminala LNG w Świnoujściu otworzyło nowy rozdział w procesie dywersyfikacji dostaw surowca o znaczeniu strategicznym dla bezpieczeństwa energetycznego państwa. Dostrzegalny jest także wzrost potencjalnego znaczenia dostarczanego tą drogą gazu dla odbiorców położonych na południe od Polski. Poszukiwanie przez Warszawę nowych źródeł LNG na rynku światowym zaowocowało podpisaniem umów na dostawy gazu z Kataru i USA. Działania te natychmiast spotkały się z ostrym komentarzem ze strony Rosji. Ostatnie ostrzeżenia kierownictwa Gazpromu skierowane do państw europejskich jasno wskazują na potencjalne skutki uniezależniania się od dostaw z kierunku wschodniego. Rosja po raz kolejny straszy partnerów zakręcaniem kurka z gazem oraz wzrostem cen surowca ${ }^{3}$. USA z kolei z jednej strony dążą do zmniejszenia znaczenia potentatów - Gazpromu i OPEC - z drugiej zaś próbują chronić własne interesy i pozycję na rynku.

Światowy rynek gazu ziemnego jest bardzo dynamiczny. W dużym stopniu wiąże się to $\mathrm{z}$ rozwojem sektora poszukiwawczo-wydobywczego oraz popularyzacją technologii do eksploatacji złóż niekonwencjonalnych i transportu surowca w stanie kriogenicznym, dzięki czemu rośnie jego dostępność 4 . Nie bez znaczenia są także prace nad mikrokogeneracją (micro-CHP), która umożliwia wykorzystanie w przydomowych urządzeniach nawet $95 \%$ zawartej w gazie energii - zarówno do generowania ciepła, jak i energii elektrycznej ${ }^{5}$. Uruchomienie dostaw LNG z kierunku morskiego było zadaniem kluczowym dla dywersyfikacji dróg importu tego paliwa w perspektywie krótkoterminowej. Perspektywy krótko- oraz średnioterminowe przewidują budowę połączeń transgranicznych ${ }^{6}$. Priorytetem Polski będzie zwiększenie ich przepustowości na granicach z państwami członkowskimi UE.

Aktualnie realizowany program rozbudowy terminala obejmuje cztery podstawowe zadania:

- budowę nowych regazyfikatorów,

- budowę nowego nabrzeża,

3 Gazprom: Europie zacznie wkrótce brakować gazu, „CIRE” [online], 9.02.2018 [dostęp: 12.02.2018], dostępny w internecie: <https://www.cire.pl/item,158410,1,0,0,0, 0,0,gazprom-europie-zacznie-wkrotce-brakowac-gazu.html>.

4 Projekt polityki energetycznej Polski do 2050 roku [wersja 0.6], Ministerstwo Gospodarki, Warszawa 2015, s. 32.

5 Tamże, s. 37.

6 Tamże, s. 14. 
- budowę trzeciego zbiornika LNG,

- budowę instalacji przeładunkowej na cysterny kolejowe i kontenery ISO7${ }^{7}$.

Krótką charakterystykę obiektu dostarczającą danych niezbędnych do dalszych rozważań przedstawia tabela 1.

\section{Tabela 1. Charakterystyka wybranych elementów terminala LNG w Świnoujściu}

\begin{tabular}{|c|c|c|}
\hline \multirow{6}{*}{ Elementy ogólne } & $\begin{array}{l}\text { Aktualne techniczne możliwości regazyfikacji w skali roku } \\
\text { (mld m LNG) }\end{array}$ & 5 \\
\hline & $\begin{array}{l}\text { Przewidywane zwiększenie możliwości regazyfikacyjnych } \\
\text { w skali roku (mld m³ LNG) }\end{array}$ & 7,5 \\
\hline & $\begin{array}{l}\text { Zakres nośności zbiornikowców LNG obsługiwanych } \\
\text { w terminalu (tys. m³ LNG) }\end{array}$ & $120-217$ \\
\hline & Objętość zbiorników składowania procesowego (tys. $\left.\mathrm{m}^{3} \mathrm{LNG}\right)^{*}$ & 320 \\
\hline & Powierzchnia obiektu na lądzie (ha) & 40 \\
\hline & Wymiary pojedynczego zbiornika lądowego (wys. $\times$ średnica, $\mathrm{m}$ ) & $42 \times 80$ \\
\hline \multirow{5}{*}{$\begin{array}{l}\text { Elementy } \\
\text { hydrotechniczne }\end{array}$} & Długość falochronu $(\mathrm{m})^{* *}$ & 2974,3 \\
\hline & Szerokość toru wodnego $(\mathrm{m})$ & 200 \\
\hline & Długość toru podejściowego do portu zewnętrznego (m) & 1742,10 \\
\hline & Głębokość techniczna $(\mathrm{m})$ & 14,5 \\
\hline & $\begin{array}{l}\text { Kubatura prac pogłębiarskich związanych z budową } \\
\text { infrastruktury hydrotechnicznej (tys. } \mathrm{m}^{3} \text { ) }\end{array}$ & 8610 \\
\hline
\end{tabular}

Źródło: „Polskie LNG” [online, dostęp: 21.04.2018], dostępny w internecie:

<www.polskielng.pl>; ,Gaz-System” [online, dostęp: 21.04.2018], dostępny w internecie: <www.gaz-system.pl>

Zaprezentowane powyżej dane pokazują ogromną przestrzeń ochranianego obiektu w obszarach lądowym, morskim, podwodnym i powietrznym. $\mathrm{W}$ związku z tworzeniem stref zewnętrznego monitorowania zagrożeń muszą one zostać zwiększone jeszcze bardziej. Zapewnienie bezpieczeństwa obiektu o znaczeniu strategicznym jest działaniem kluczowym, a zatem powinno być traktowane priorytetowo w prowadzeniu badań i wdrażaniu nowoczesnych technologii umożliwiających podniesienie poziomu jego ochrony. Specyficzne usytuowanie gazoportu na styku dwóch środowisk stwarza bowiem szczególne wymagania i wiąże się z koniecznością zastosowania adekwatnych środków.

7 Jakubowski: Program rozbudowy terminala nabiera tempa, „Polskie LNG” [online], 17.04.2018 [dostęp: 21.04.2018], dostępny w internecie: <https://www.polskielng.pl/nc/ biuro-prasowe/aktualnosci/wiadomosc/artykul/201520/>. 


\section{Zagrożenia dla funkcjonowania terminala LNG}

Podejmując próbę identyfikacji zagrożeń, wzięto pod uwagę opinie autorytetów z dziedziny terroryzmu morskiego (Krzysztofa Kubiaka i Piotra Mickiewicza), analizy dokonane przez budowniczych terminala LNG oraz badania własne. Jako potencjalne cele oddziaływania z kierunku morskiego przyjęte zostały zarówno infrastruktura terminala i obsługiwany gazowiec (stanowiący wtedy niejako element gazoportu), jak również metanowiec ${ }^{8}$ znajdujący się na torze podejściowym, gdyż skutki ataku na taki statek mogą bezpośrednio oddziaływać na funkcjonowanie terminala (tabela 2).

Tabela 2. Potencjalne środki ataku na port lub gazowiec

\begin{tabular}{|c|c|c|c|c|}
\hline \multirow{2}{*}{$\begin{array}{c}\text { Kierunek } \\
\text { ataku }\end{array}$} & \multirow{2}{*}{ Środek ataku } & \multirow{2}{*}{ Dostępność } & \multicolumn{2}{|c|}{ Potencjal zniszczenia } \\
\hline & & & portu morskiego & gazowca \\
\hline \multirow{9}{*}{ Morski } & szybka jednostka & wysoka & wysoki & wysoki \\
\hline & ostrzał z morza & niska & średni & średni \\
\hline & $\begin{array}{l}\text { środki zdalnie sterowane ROV } \\
\text { lub AUV }\end{array}$ & wysoka & wysoki & wysoki \\
\hline & miny morskie & średnia & - & wysoki \\
\hline & nurek & wysoka & - & wysoki \\
\hline & $\begin{array}{l}\text { miniaturowe okręty } \\
\text { podwodne }\end{array}$ & niska & - & wysoki \\
\hline & WBIED* $^{*}$ & wysoka & - & wysoki \\
\hline & uprowadzenie & średnia & - & wysoki \\
\hline & atak jednostki upozorowanej ${ }^{* *}$ & niska & - & wysoki \\
\hline \multirow{4}{*}{$\begin{array}{l}\text { Powietrzny } \\
\text { z morza }\end{array}$} & samolot pasażerski & niska & wysoki & wysoki \\
\hline & awionetka & niska & wysoki & wysoki \\
\hline & motolotnia & średnia & średni & średni \\
\hline & $\mathrm{BAL}^{* * *}$ & średnia & średni & średni \\
\hline \multicolumn{5}{|c|}{$\begin{array}{l}\text { * WBIED (water borne improvised explosive device) - morskie improwizowane } \\
\text { urządzenie wybuchowe, zawierające niszczące, śmiertelne, szkodliwe środki } \\
\text { pirotechniczne lub zapalające środki chemiczne przeznaczone do niszczenia, } \\
\text { unieszkodliwiania, nękania lub odwracania uwagi. Może zawierać materiały wojskowe, } \\
\text { ale zwykle skonstruowane jest z elementów pochodzących z innych źródeł. } \\
{ }^{* *} \text { Jednostka upozorowana zewnętrznie przypomina statki służb administracji morskiej, } \\
\text { służb portowych itp. (malowane zewnętrzne oznaki przynależności). } \\
{ }^{* * *} \text { BAL - bezpilotowy aparat latający (lub BSP - bezpilotowy system powietrzny). }\end{array}$} \\
\hline
\end{tabular}

Źródło: oprac. własne na podstawie: R. Miętkiewicz, Wykorzystanie bezzatogowych jednostek nawodnych $w$ zabezpieczaniu morskich obiektów infrastruktury krytycznej,

Akademia Marynarki Wojennej, Gdynia 2018, s. 51, 53

8 Popularna nazwa zbiornikowca LNG. 
Przedstawione dane pokazują, że potencjalne środki ataku to duża grupa obiektów o szerokim zakresie dostępności (od niskiej do wysokiej). Udane ich użycie może doprowadzić do średniego lub poważnego zakłócenia funkcjonowania gazoportu oraz zbiornikowca LNG. Zaproponowanym przez autora rozwiązaniem pozwalającym na wczesne wykrywanie symptomów zagrożeń, zmniejszenie prawdopodobieństwa wystąpienia ataku oraz minimalizację jego skutków jest wykorzystanie technologii bezzałogowych.

\section{Systemy autonomiczne/bezzalogowe}

Notowany w ciągu ostatnich kilkunastu lat dynamiczny rozwój technologii bezzałogowych determinowany był głównie wykorzystywaniem ich do zapewniania szeroko rozumianego bezpieczeństwa oraz potrzebami militarnymi. Wśród setek konstrukcji zdecydowany prym wiodą aparaty zdolne do realizacji misji w powietrzu. Doświadczenia konfliktów w Iraku i Afganistanie przyczyniły się do powstania wielu wersji platform bojowych, ale także przeniesienia ich zastosowania w obszary dotychczas pozbawione tych technologii.

W ogromnej rodzinie systemów bezzałogowych (ang. Unmanned Vehicles UV) wyróżniamy systemy powietrzne (ang. Unmanned Aerial Vehicles - UAV) oraz morskie, w tym nawodne (ang. Unmanned Surface Vehicles - USV) i podwodne (ang. Unmanned Underwater Vehicles - UUV). Całkowicie odmienną grupę tworzą natomiast systemy lądowe (ang. Unmanned Ground Vehicles UGV), jednak z uwagi na założenia niniejszego tekstu nie będą tu rozpatrywane.

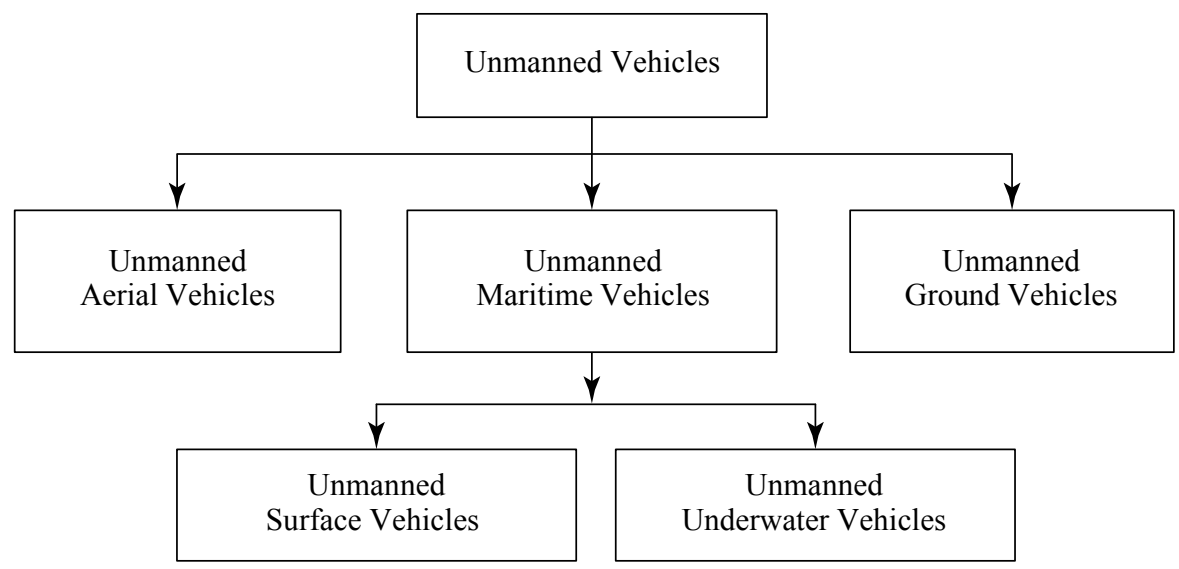

Rys. 1. Ogólny podział jednostek bezzałogowych

Źródło: oprac. własne na podstawie: The Navy Unmanned Surface Vehicle (USV) Master Plan, Department of the Navy, Washington 2002 
Jako pierwsze krótkiej analizie poddane zostaną systemy powietrzne, charakteryzujące się największą prędkością przemieszczania się oraz możliwością dostarczenia szybkiej informacji, niezbędnej do stworzenia całościowego obrazu sytuacji (monitorowania) dla potrzeb bezpieczeństwa. Dokumenty NATO wprowadziły trzy klasy jednostek (rys. 2), z których największą grupę tworzą aparaty przeznaczone do zadań rozpoznawczych na poziomie operacyjnym. W przypadku zastosowania będącego głównym obszarem zainteresowania niniejszego tekstu celowe zdaje się wskazanie klas II oraz I (z pewnymi ograniczeniami), jako przeznaczonych do realizacji zadań związanych z ochroną obiektu o znaczeniu strategicznym dla bezpieczeństwa energetycznego.

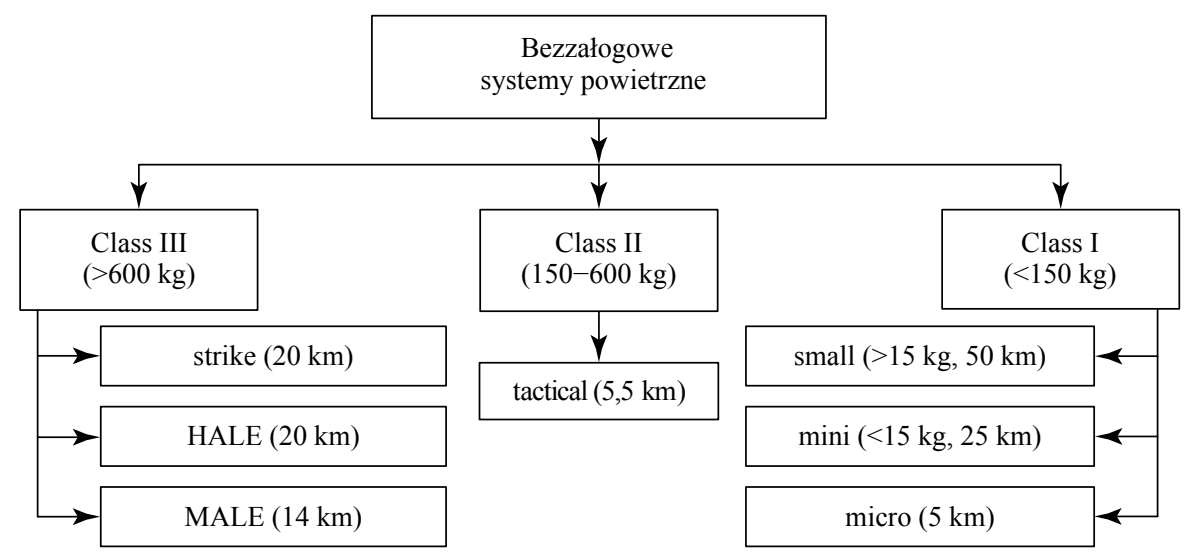

Rys. 2. Wprowadzona przez ATP 3.3.7 klasyfikacja UAS (ang. Unmanned Aerial Systems) wraz z masą i pulapem operacyjnym

Źródło: ATP 3.3.7 Guidance for the training of Unmanned Aircraft Systems (UAS) operators, edition B, version 1, NATO Standardization Agency 2014, s. 1-4

Podane powyżej wartości uzupełnia parametr zasięgu operacyjnego - bardzo istotny z uwagi na możliwość wykorzystania UAS w aplikacjach związanych z bezpieczeństwem:

- klasa III (bez ograniczeń),

- klasa II $(200 \mathrm{~km})$,

- klasa I (small - $50 \mathrm{~km}$, mini - $25 \mathrm{~km}$, micro - $5 \mathrm{~km}$ ).

W Polsce UAS znalazły wiele zastosowań i są coraz powszechniej używane przez Siły Zbrojne, Policję, Straż Graniczną, Straż Pożarną i inne służby podsystemu ochronnego RP. Wśród zasadniczych misji realizowanych nad obszarem terminala LNG w Świnoujściu (przestrzeni powietrznej nad morzem i lądem) należy wskazać:

- monitorowanie obszaru nadmorskiego po trasie patrolu celem identyfikacji jednostek wskazanych np. przez systemy radarowe, 
- dostarczanie danych z sensorów pokładowych celem uzyskania pełnej świadomości sytuacyjnej wraz z monitoringiem ekologicznym,

- monitoring stanu infrastruktury w górnej półsferze (lądowe zbiorniki LNG, linie przesyłowe itp.),

- elementy misji ratowniczych.

Obszar morski jest domeną wykorzystania systemów bezzałogowych obejmujących środki operujące na powierzchni morza oraz zdolne do penetracji głębin morskich. Za bezzałogowe platformy nawodne uznaje się wszystkie jednostki operujące na powierzchni wody, względnie utrzymujące z nią kontakt przez większą część misji, pozbawione przy tym bezpośredniej obsługi operatorskiej w postaci załogi pokładowej ${ }^{9}$. W ostatnich latach kilka razy próbowano wprowadzić klasyfikację platform tego typu. Jednostki akademickie oraz profesjonalne podmioty sektora morskiego i militarnego projektują setki obiektów o różnej wielkości, możliwościach, przeznaczeniu, a także poziomach autonomiczności ${ }^{10}$. Platformy bezzałogowe wraz z zabezpieczającymi ich działanie podsystemami - jak wyposażenie, łączność, stanowisko dowodzenia, konsole, oprogramowanie, personel itd. - tworzą systemy bezzałogowe ${ }^{11}$.

W analizie systemów operujących na powierzchni morza uwagę zwraca duża rozpiętość wielkości jako głównego parametru różnicującego te jednostki. Jest on jednocześnie determinantem autonomiczności (w rozumieniu długości trwania misji), zasięgu operacyjnego czy dzielności morskiej.

Warunki miejscowe terminala LNG (głównie fakt, że obiekt posadowiony został na otwartym morzu) wymagają do realizacji misji w basenach portowych i na torze podejściowym (brak osłony falochronu) jednostek o długości przynajmniej $7 \mathrm{~m}$. Przykładem platformy, która osiągnęła gotowość zastosowania w ramach ochrony rejonu portu morskiego, jest Seagull.

Podstawowe działania USV w obszarze utrzymania bezpieczeństwa terminala LNG obejmowały będą:

- monitoring stanu infrastruktury hydrotechnicznej z kierunku morskiego;

- monitoring ruchu jednostek w obszarze toru wodnego (podejściowego);

- podejmowanie misji interwencyjnych wobec jednostek/obiektów naruszających strefę zabronioną;

9 The Navy Unmanned Surface Vehicle (USV) Master Plan, Department of the Navy, Washington 2002, s. XI.

10 R. Miętkiewicz, Wykorzystanie bezzałogowych systemów..., s. 225.

11 Tenże, Potencjalne obszary wykorzystania autonomicznych platform nawodnych w Marynarce Wojennej RP, [w:] ,Technologie morskie dla obronności i bezpieczeństwa”. VII Międzynarodowa Konferencja Naukowo-Techniczna, Akademia Marynarki Wojennej, Gdynia 2016, s. 317. 


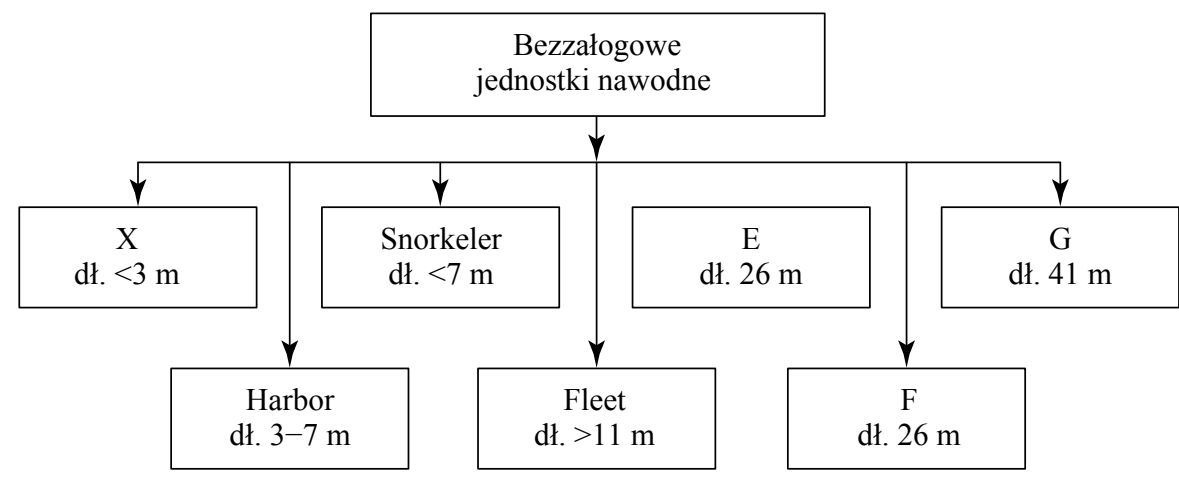

Rys. 3. Klasy bezzalogowych jednostek nawodnych wg US NAVY oraz RAND

Źródło: oprac. własne na podstawie: U.S. Navy employment options for Unmanned Surface Vehicles (USVs), RAND, National Defense Research Institute, 2013, s. 50

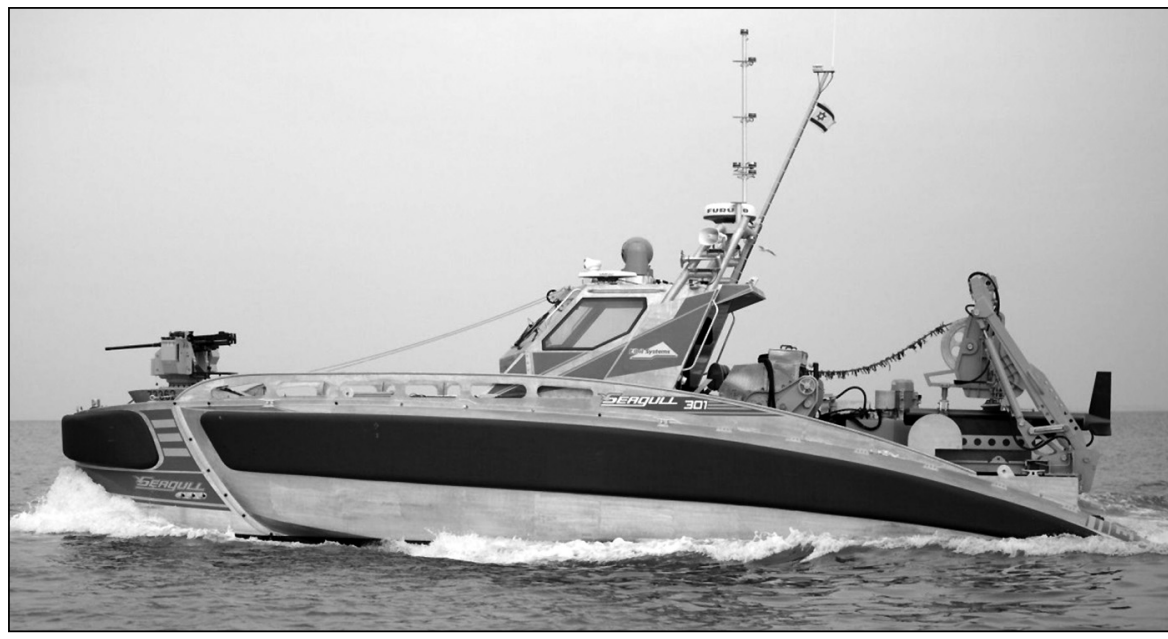

Fot. 1. Bezzałogowa jednostka nawodna Seagull z pokładowym systemem wodowania sonaru holowanego i zestawem strzeleckim

Źródło: „Habbeké Shipyard” [online, dostęp: 24.04.2018], dostępny w internecie: <www.habbeke.nl/wp-content/uploads/MG_2845A.jpg>

- realizację zadań pod powierzchnią morza - po wyposażeniu jednostki w pojazd ROV (ang. Remotely Operated Vehicle);

- monitoring ekologiczny, kontrolowanie stanu atmosfery;

- w ograniczonym zakresie podejmowanie misji ratowniczych.

Od wielu lat eksploatację głębin morskich wspierają zaawansowane systemy bezzałogowych pojazdów podwodnych. Osiągnęły one bardzo wysoki poziom techniczny, czego dowiodło samodzielne pokonanie Atlantyku 


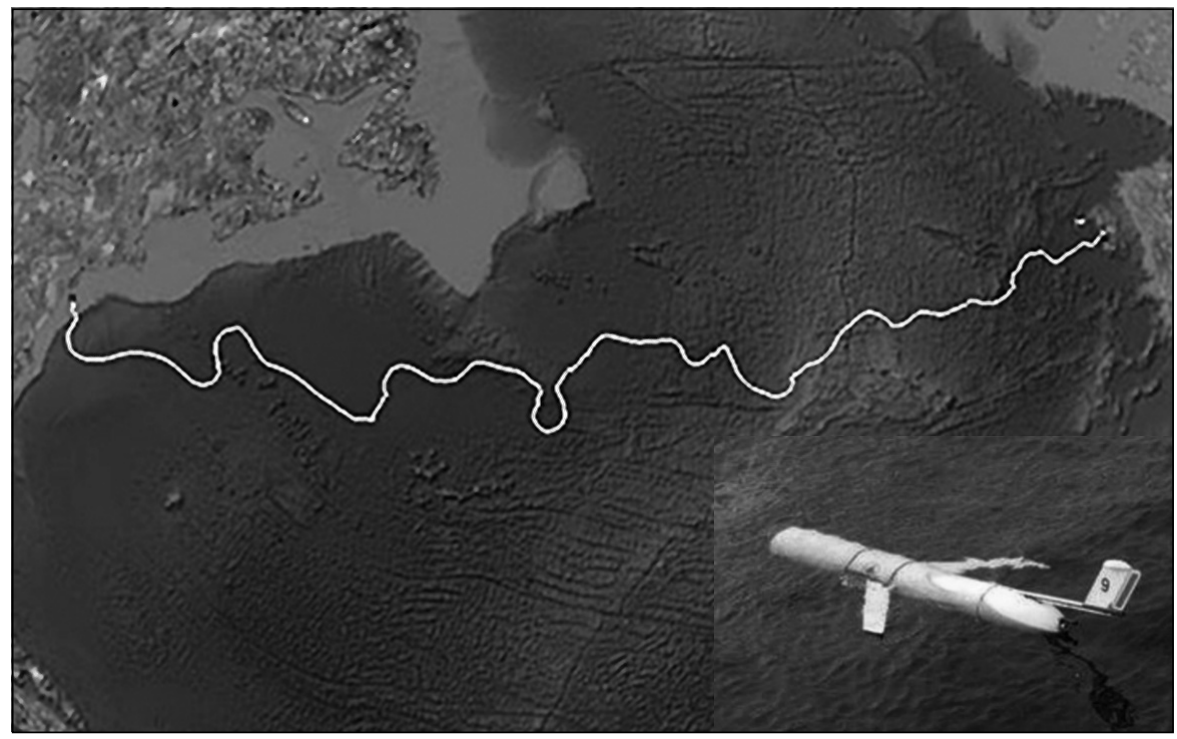

Rys. 4. Trasa atlantyckiej podróży pojazdu UUV

Źródło: „Rutgers” [online, dostęp: 23.04.2018], dostępny w internecie: <rucool.marine. rutgers.edu/atlantic/images/track.jpg>; ,Solar Navigator” [online, dostęp: 23.04.2018], dostępny w internecie: $<$ www.solarnavigator.net/world_solar_challenge/solar_challenge_ images/slocum_autonomous_sea_glider_survey_vessel_surfaced_tail_fin.jpg >

przez RU-27 „Scarlet Knight”. W ciągu 221 dni między kwietniem a grudniem 2009 r. pojazd przebył 7409,6 km (rys. 4) ${ }^{12}$.

Marynarka Wojenna RP dysponuje już kilkuletnim doświadczeniem w wykorzystywaniu tego typu pojazdów, głównie w zakresie poszukiwania obiektów niebezpiecznych (Gavia). Wraz z realizacją kolejnych etapów procesu modernizacji sił morskich pozyskiwane są nowoczesne, zaawansowane technologie podwodne (Double Eagle, Hugin).

Współcześnie praktycznie nie można sobie wyobrazić służby państwowej, w której systemy autonomiczne nie znalazłyby zastosowania w podnoszeniu poziomu, zwiększaniu efektywności oraz obniżaniu kosztów prowadzonych działań. Wpływają one na skrócenie czasu działania, co przy jego permanentnym deficycie $\mathrm{w}$ dynamicznym środowisku bezpieczeństwa należy uznać za kluczowe. Ogromnymi zaletami systemów autonomicznych są też oddalenie źródeł zagrożeń od obsługi oraz (przy odpowiednim wyposażeniu) możliwość natychmiastowego przeciwstawienia się niebezpieczeństwom

12 D. Brown, Submersible glider spent months collecting data on Atlantic waters, „The Washington Post" [online], 15.12.2009 [dostęp: 23.04.2018], dostępny w internecie: <www. washingtonpost.com/wp-dyn/content/article/2009/12/14/AR2009121402861.html>. 


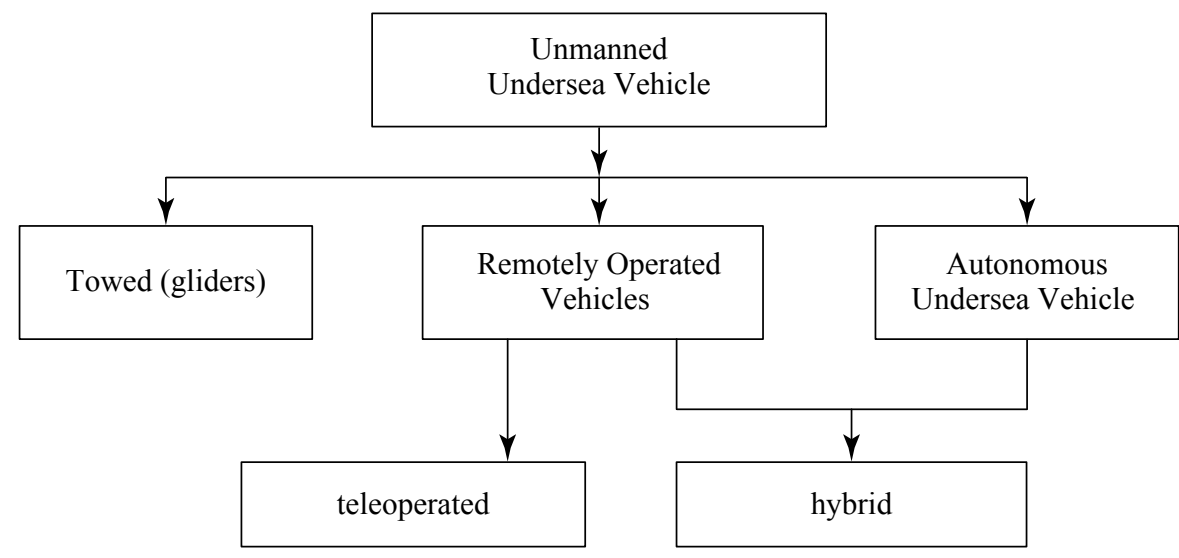

\section{Rys. 5. Podzial pojazdów UUV}

Źródło: oprac. własne na podstawie: R. Button, J. Kamp, T. Curtin, J. Dryden, A survey of missions for Unmanned Undersea Vehicles, National Defense Research Institute, RAND, 2009, s. 115, dostępny w internecie [dostęp: 12.02.2018]: <www.rand.org/content/dam/rand/ pubs/monographs/2009/RAND_MG808.pdf>

$(\text { reakcja })^{13}$. Do wad zaliczyć trzeba nieuregulowany status prawny stosowania systemów operujących w środowisku morskim, w przeciwieństwie do mającego umocowanie prawne wykorzystania bezpilotowych systemów latających (BSL). Dowodzi to, że rozwój technologii znacznie wyprzedza regulacje legislacyjne dotyczące użycia systemów autonomicznych w poszczególnych domenach. Do rozwiązania pozostają także kwestie związane z transmisją ogromnych ilości danych online, dokładnością prowadzenia nawigacji podwodnej, wysokim poziomem autonomiczności czy wydajności zasilania oraz systemów napędowych.

Zakres zadań jednostek UUV powinien obejmować:

- monitorowanie stanu infrastruktury hydrotechnicznej w dolnej półsferze (toń wodna, dno morskie);

- tworzenie mobilnych barier przeciwko zagrożeniom podwodnym;

- tworzenie map dna morskiego celem zbudowania bazy danych ukształtowania powierzchni oraz obiektów zalegających na dnie;

- poszukiwanie, klasyfikację, identyfikację i niszczenie obiektów niebezpiecznych (w tym ładunków improwizowanych);

- hydrografię morską;

- badanie stanu kabli, gazociągów i rurociągów podwodnych.

13 R. Miętkiewicz, Klasyfikacja bezzałogowych jednostek nawodnych, [w:] Systemy bezzatogowe, red. K. Gawrysiak, Akademia Marynarki Wojennej, Gdynia 2017, s. 31. 


\section{Architektura połączona systemów bezzałogowych}

Zaprezentowany zakres potencjalnych misji poszczególnych rodzajów systemów autonomicznych mających odpowiadać za przeciwstawianie się zagrożeniom z kierunku morskiego (wliczając górną półsferę) obejmuje głównie monitorowanie przestrzeni w celu wykrycia obiektów niepożądanych. Co istotne, w każdym z systemów można wskazać zarówno cechy predysponujące, jak i ograniczenia, które znacząco wpływają na wykonywanie zadań (tabela 3).

Tabela 3. Dodatnie i ujemne cechy systemów bezzalogowych operujących w środowisku morskim

\begin{tabular}{|c|c|c|c|}
\hline Typ & Cechy dodatnie & Cechy ujemne & Współpraca \\
\hline $\begin{array}{l}\text { Autonomiczne } \\
\text { systemy } \\
\text { nawodne } \\
\text { (ASV) }\end{array}$ & $\begin{array}{l}\text { - duża prędkość prze- } \\
\text { mieszczania się } \\
\text { - możliwość podejmo- } \\
\text { wania szerokiej palety } \\
\text { misji, w tym zwalczania } \\
\text { zagrożeń na powierzch- } \\
\text { ni (dzięki systemom } \\
\text { uzbrojenia) } \\
\text { - możliwość poszu- } \\
\text { kiwania obiektów } \\
\text { niebezpiecznych w toni } \\
\text { i na dnie morza (dzięki } \\
\text { wyposażeniu) } \\
\text { - możliwość współpracy } \\
\text { z systemami ASV i AAV } \\
\text { - pełnienie roli jednostki } \\
\text { matki } \\
\text { - możliwość zastosowania } \\
\text { alternatywnych źródeł } \\
\text { energii } \\
\text { - możliwość monta- } \\
\text { żu znacznej liczby } \\
\text { sensorów } \\
\text { - budowa modułowa }\end{array}$ & $\begin{array}{l}\text { - } \text { horyzontalny } \\
\text { zasięg obserwacji } \\
\text { (zależny od wyso- } \\
\text { kości wyniesienia } \\
\text { sensorów) } \\
\text { - ograniczone } \\
\text { możliwości użycia } \\
\text { w złych warunkach } \\
\text { hydrometeoro- } \\
\text { logicznych } \\
\text { - przy niewiel- } \\
\text { kich rozmiarach } \\
\text { ograniczenia } \\
\text { w autonomiczności }\end{array}$ & $\begin{array}{l}\text { - przekazywanie } \\
\text { pozycji AAV } \\
\text { - jednostka matka } \\
\text { dla AAV } \\
\text { - retranslacja } \\
\text { sygnałów } \\
\text { - dostarczenie pojaz- } \\
\text { du AUV bezpo- } \\
\text { średnio w miejsce } \\
\text { zdarzenia (mini- } \\
\text { malizacja czasu) } \\
\text { - możliwość two- } \\
\text { rzenia mobilnych } \\
\text { stanowisk monito- } \\
\text { rowania systemów } \\
\text { - dostarczenie zasi- } \\
\text { lania jednostkom } \\
\text { ASV i AUV w wa- } \\
\text { riancie bazowania } \\
\text { pokładowego }\end{array}$ \\
\hline $\begin{array}{l}\text { Autonomiczne } \\
\text { systemy } \\
\text { podwodne } \\
\text { (AUV) }\end{array}$ & $\begin{array}{l}\text { - możliwość dokony- } \\
\text { wania klasyfikacji } \\
\text { i identyfikacji obiektów } \\
\text { podwodnych } \\
\text { - odporność na warunki } \\
\text { hydrometeorologiczne } \\
\text { - rosnąca wraz z pracami } \\
\text { nad systemami zasilania } \\
\text { wydajność baterii } \\
\text { - budowa modułowa }\end{array}$ & \begin{tabular}{|l} 
- utrudniona \\
łączność \\
- utrudnione prze- \\
syłanie danych \\
w relacji online \\
- trudności w prowa- \\
dzeniu nawigacji \\
podwodnej \\
- skomplikowana \\
budowa (wysokie \\
koszty nabycia)
\end{tabular} & $\begin{array}{l}\text { - wczesne wykrycie } \\
\text { symptomów zagro- } \\
\text { żeń w toni wodnej } \\
\text { (dno morza) } \\
\text { - przekazywa- } \\
\text { nie informacji } \\
\text { na jednostkę ASV } \\
\text { (światłowód) }\end{array}$ \\
\hline
\end{tabular}




\begin{tabular}{|l|l|l|l|}
\hline \multicolumn{1}{|c|}{ Typ } & Cechy dodatnie & Cechy ujemne & Wspólpraca \\
\hline & - duża prędkość prze- & - mała odporność & - retranslacja \\
& mieszczania się & na warunki hydro- & sygnałów \\
& - duży zasięg prowadzo- & meteorologiczne & - wczesne wykrycie \\
& nej obserwacji & - podatność & zagrożeń \\
Autonomiczne & możliwość mon- & na zakłócenia & - wskazanie \\
systemy & towania modułów & zewnętrzne & ASV obiektów \\
powietrze & uzbrojeniowych & - zależnie od wiel- & niebezpiecznych \\
(AAV) & dla górnopłatów moż- & kości ograniczone & \\
& liwość pracy w trybie & możliwości mon- & \\
& „szybowiec” & towania systemów & \\
& dla wiropłatów moż- & pokładowych & \\
& liwość pracy w trybie & & \\
& „zawis” & & \\
\hline
\end{tabular}

Źródło: oprac. własne

Na świecie pojawiają się już bardzo interesujące koncepcje umożliwiające operowanie jednostkami AAV i AUV z pokładów bezzałogowych jednostek nawodnych. Rozwiązania takie obejmują start i lot na uwięzi platform powietrznych, które dzięki zasilaniu z jednostki matki (np. w przypadku wiropłatów) mogą utrzymywać się w powietrzu znacznie dłużej, niż gdyby wykorzystywały zasilanie miejscowe. Ponadto dane zebrane przez sensory przesyłane są do komputera pokładowego w sposób bezpieczny i maksymalnie szybki (światłowód).

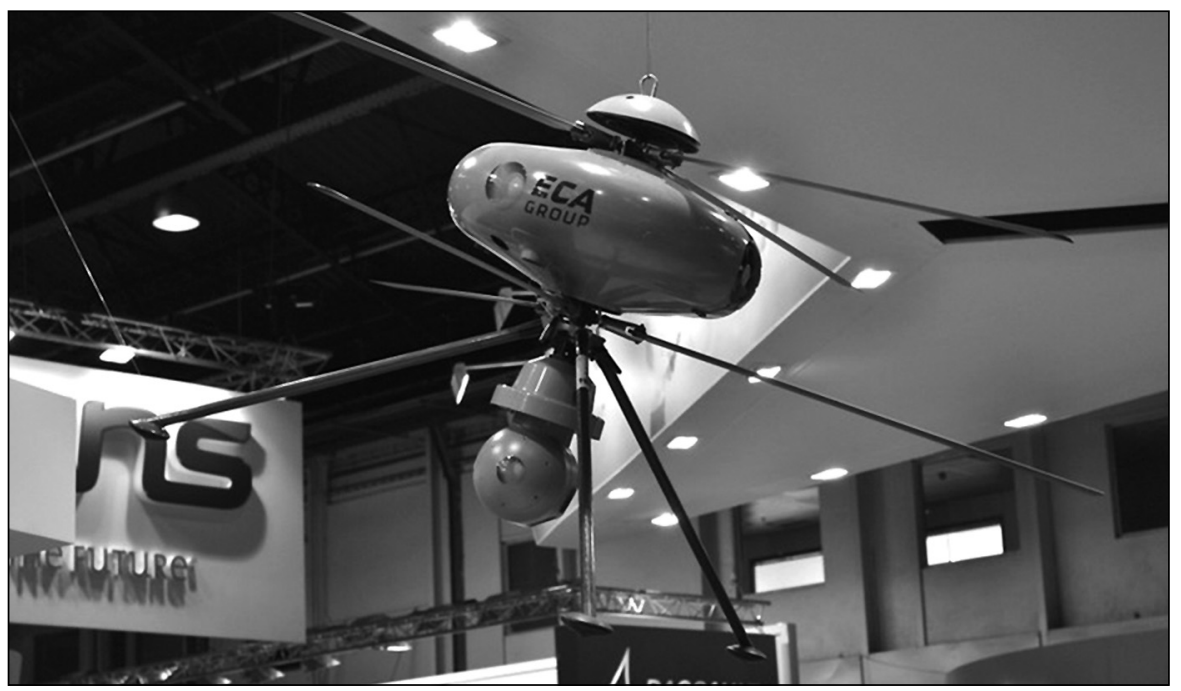

Fot. 2. Maszt wirtualny, propozycja ECA

Źródło: Krajowy maszt wirtualny dla polskich okrętów, „Defence 24” [online], 13.02.2017 [dostęp: 28.04.2018], dostępny w internecie: <https://www.defence24.pl/ krajowy-maszt-wirtualny-dla-polskich-okretow> 
W przypadku pojazdów AUV pokłady jednostek wyposażane są w systemy wodowania i odzyskiwania tego typu platform bądź nośników holowanych stacji hydrolokacyjnych. Przykładem bezzałogowego systemu nawodnego z sonarem holowanym jest wspomniany już Seagull (tabela 4).

Tabela 4. Charakterystyka pojazdu Seagull

\begin{tabular}{|l|l|}
\hline Długość jednostki (m) & \multicolumn{1}{|c|}{12} \\
\hline Prędkość maks. (w.) & \multicolumn{1}{|c|}{2500} \\
\hline Ladowność (kg) & \multicolumn{1}{c|}{96} \\
\hline Autonomiczność (h) & $\begin{array}{l}\text { - monitoring podwodny } \\
\text { - poszukiwanie min, trałowanie min } \\
\text { - poszukiwanie okrętów podwodnych } \\
\text { - walka elektroniczna* } \\
\text { - poszukiwanie, zwalczanie okrętów podwodnych } \\
\text { - bezpieczeństwo morskie }\end{array}$ \\
\hline $\begin{array}{l}\text { * Walka elektroniczna obejmuje rozpoznanie źródeł emisji elektromagnetycznej oraz } \\
\text { dezorganizację pracy urządzeń elektronicznych przeciwnika z wykorzystaniem energii } \\
\text { elektromagnetycznej. }\end{array}$ \\
\hline
\end{tabular}

Źródło: Seagull, „Naval Drones” [online], 28.06.2016 [dostęp: 22.04.2018], dostępny w internecie: <www.navaldrones.com/Seagull.html>

\section{Zakończenie}

Łączenie architektur różnych systemów bezzałogowych pozwala na efektywne wzajemne niwelowanie przez nie swoich słabych stron i wypełnianie powstałych nisz. Wyniki przeprowadzonych analiz pozwalają stwierdzić, że:

- terminal LNG w Świnoujściu jest obiektem bardzo wymagającym pod względem utrzymania bezpieczeństwa funkcjonowania dostaw surowca o znaczeniu strategicznym;

- bezpieczeństwo terminala jako obiektu o znaczeniu strategicznym wymaga wykorzystania efektywnych nowoczesnych środków;

- niezbędne jest opracowanie procedur wykorzystania systemów bezzałogowych w strukturach służb odpowiedzialnych za utrzymanie bezpieczeństwa obiektu;

- niezbędne jest dostosowanie regulacji prawnych do dynamicznie rozwijającego się rynku systemów bezzałogowych i opracowanie zasad ich funkcjonowania;

- rozwój technologiczny poszczególnych systemów sprzyja wzrostowi ich możliwości i tworzeniu wspólnych połączonych systemów operacyjnych; 
- dalsze badania powinny być ukierunkowane na sprecyzowanie taktyczno-technicznych parametrów platform i tworzących je systemów (dobór sensorów, efektorów, scenariusze misji, algorytmy postępowania).

Przeprowadzona w niniejszym tekście analiza pozwala na pozytywną weryfikację postawionej hipotezy badawczej. Połączone architektury systemów bezzałogowych (powietrznych, nawodnych i podwodnych) mogą wpłynąć na podniesienie poziomu bezpieczeństwa terminala $\mathrm{LNG}$, zwłaszcza poprzez:

- tworzenie stref buforowych;

- monitorowanie stanu bezpieczeństwa obiektu docelowo w czterech sferach: powietrznej, nawodnej, podwodnej oraz brzegowej;

- umożliwienie tworzenia pełnego obrazu sytuacji operacyjnej i dowodzenia/kierowania działaniami;

- zwiększenie wydajności w porównaniu z systemami opartymi o wykorzystanie operatora (monitoring wizyjny);

- skrócenie czasu między wykryciem niebezpieczeństwa a podjęciem przeciwdziałania;

- możliwość podejmowania akcji interwencyjnych i ratowniczych.

\section{Bibliografia}

ATP 3.3.7 Guidance for the training of Unmanned Aircraft Systems (UAS) operators, edition B, version 1, NATO Standardization Agency 2014.

Brown D., Submersible glider spent months collecting data on Atlantic waters, ,The Washington Post" [online], 15.12.2009 [dostęp: 23.04.2018], dostępny w internecie: <www.washingtonpost.com/wp-dyn/content/article/2009/12/14/AR2009121402861.html>.

Button R., Kamp J., Curtin T., Dryden J., A survey of missions for Unmanned Undersea Vehicles, National Defense Research Institute, RAND, 2009, dostępny w internecie [dostęp: 12.02.2018: <www.rand.org/content/dam/rand/pubs/monographs/2009/RAND_ MG808.pdf>.

Gazprom: Europie zacznie wkrótce brakować gazu, „CIRE” [online], 9.02 .2018 [dostęp: 12.02.2018], dostępny w internecie: $<$ https://www.cire.pl/item, 158410,1,0,0,0,0,0,gazpromeuropie-zacznie-wkrotce-brakowac-gazu.html>.

„Gaz-System” [online, dostęp: 21.04.2018], dostępny w internecie: <www.gaz-system.pl>.

„Habbeké Shipyard” [online, dostęp: 24.04.2018], dostępny w internecie: <www.habbeke.nl/ wp-content/uploads/MG_2845A.jpg>.

Jakubowski: Program rozbudowy terminala nabiera tempa, „Polskie LNG” [online], 17.04.2018 [dostęp: 21.04.2018], dostępny w internecie: <https://www.polskielng.pl/nc/ biuro-prasowe/aktualnosci/wiadomosc/artykul/201520/>.

Krajowy maszt wirtualny dla polskich okrętów, „Defence 24” [online], 13.02.2017 [dostęp: 28.04.2018], dostępny w internecie: $<$ https://www.defence24.p1/krajowy-maszt-wirtualny-dla-polskich-okretow>. 
Miętkiewicz R., Klasyfikacja bezzałogowych jednostek nawodnych, [w:] Systemy bezzałogowe, red. K. Gawrysiak, Akademia Marynarki Wojennej, Gdynia 2017.

Miętkiewicz R., Potencjalne obszary wykorzystania autonomicznych platform nawodnych w Marynarce Wojennej RP, [w:] „Technologie morskie dla obronności i bezpieczeństwa”. VII Międzynarodowa Konferencja Naukowo-Techniczna, Akademia Marynarki Wojennej, Gdynia 2016.

Miętkiewicz R., Unmanned surface vehicles in maritime critical infrastructure protection applications - LNG terminal in Świnoujście, „Scientific Journal of Polish Naval Academy” 2018, R. 59, nr 2 (213).

Miętkiewicz R., Wykorzystanie bezzałogowych jednostek nawodnych $w$ zabezpieczaniu morskich obiektów infrastruktury krytycznej, Akademia Marynarki Wojennej, Gdynia 2018.

Miętkiewicz R., Wykorzystanie bezzałogowych systemów morskich w tworzeniu obrazu sytuacji morskiej, [w:] Nauki społeczne i ekonomiczne - węzłowe zagadnienia, red. J. Żylińskia, I. Przychocka, Uczelnia Techniczno-Handlowa im. Heleny Chodkowskiej, Warszawa 2017.

Nauki społeczne i ekonomiczne - węzłowe zagadnienia, red. J. Żylińskia, I. Przychocka, Uczelnia Techniczno-Handlowa im. Heleny Chodkowskiej, Warszawa 2017.

The Navy Unmanned Surface Vehicle (USV) Master Plan, Department of the Navy, Washington 2002.

„Polskie LNG” [online, dostęp: 21.04.2018], dostępny w internecie: <www.polskielng.pl>.

Projekt polityki energetycznej Polski do 2050 roku [wersja 0.6], Ministerstwo Gospodarki, Warszawa 2015

„Rutgers” [online, dostęp: 23.04.2018], dostępny w internecie: <rucool.marine.rutgers.edu/ atlantic/images/track.jpg>.

„Solar Navigator” [online, dostęp: 23.04.2018], dostępny w internecie: <www.solarnavigator. net/world_solar_challenge/solar_challenge_images/slocum_autonomous_sea_glider_survey_vessel_surfaced_tail_fin.jpg>.

„Technologie morskie dla obronności i bezpieczeństwa”. VII Międzynarodowa Konferencja Naukowo-Techniczna, Akademia Marynarki Wojennej, Gdynia 2016.

U.S. Navy employment options for Unmanned Surface Vehicles (USVS), RAND, National Defense Research Institute, 2013. 